\title{
Cycle Time Reduction to Increase Productivity of DVD Production
}

\author{
Hasibur Rahaman ${ }^{1}$, Suman Nihar ${ }^{2}$, Habib Masum ${ }^{3}$ \\ ${ }^{1,2,3}$ Department of Mechanical Engineering, Ghani Khan Choudhury Institute of Engineering and Technology, Malda, W.B., India \\ (Centrally funded Institute and Established by MHRD, Govt. of India)
}

\begin{abstract}
The prime objective of any enterprise is to earn profit by selling their goods in market and/or providing services to customers. These days, many firms are focusing on continuous improving in quality and customer delight. A continuous search for areas of improvement in the production system is needed to survive in the trend of globalization. To achieve this objective, the firms need to convert some inputs like manpower, materials, capital, energy, information, etc. into useful outputs like finished products and services in required quantity and quality. To profit as corporate goal the focus now is on good quality, customer satisfaction and improvement in the product and production system. Productivity is defined in term of utilization of resources, like material and labor. In simple term productivity is the ratio of output to input. Therefore, productivity can be improved by a) controlling input parameters, b) improved process, c) advanced technology. To increase the production quantity and reduce manufacturing cost in DVD manufacturing, the cycle time of DVD production was reduced by controlling some input parameters and its effects which have been discussed in this paper. This has considerably improved the productivity of DVD production.
\end{abstract}

Keywords: DVD, productivity, cycle time reduction.

\section{Introduction}

Cycle time reduction is one of the most important parameters of the successful manufacturing process today. More and more customers desire that manufacturers quickly respond to their needs, deliver perfect quality product on time. This trend, which will continue, has lead companies to focus more attention on their order-to-delivery cycle time without compromising the quality. Order-to-delivery cycle time reduction is often a good place to start in the overall effort to improve operations because it can be done without large capital investment. Clearly, long cycle times cause large inventories, high cost and poor customer service. As a result, many manufacturers are streaming internal and external supply operations to reduce overall order-to-delivery cycle time.

Costumers generally evaluate a supplier's performance, on four factors: product performance (features), prices, quality and delivery within a reasonable time. In the past years, manufacturers made product and stored them into finished goods (i.e. time "make-to-stock" mode) and waited for customers to place orders to buy them. In this "push" production model, large runs of batches of products are proceed using highly inaccurate sales forecast. In contrast, today it is the customer who largely dictates what products are manufactured and when. The customer says ' 'I' will let you know what and how many I want; when I'm ready to buy; and then you ship it exactly as I want the product configured; and in a very short lead time;". Cycle time is the time required to complete a given process. Cycle time reduction is identifying and implementing more efficient ways to do things. Reducing cycle time requires eliminating or reducing non-value-added activity, which is defined as any activity that does not add value to the product. An example of non value added activity in which cycle time can be reduced or eliminated include repair due to defects, machine setup, inspection, test and schedule delays, reducing cycle time will have implemented. Reducing cycle time gives benefits as reduced costs, increased throughput, improved communications, nominal process variability, scheduled integrity, and improved on-time-delivery.

\section{Productivity}

Productivity is a measure of output from a production process, per unit of input. For example, labor productivity is typically measured as a ratio of output per labor-hour, an input. Productivity may be conceived as a metric of the technical or engineering efficiency of production. As such, the emphasis is on quantitative metrics of input, and sometimes output. Productivity is distinct from metrics of allocative efficiency, which take into account both the monetary value (price) of what is produced and the cost of inputs used, and also distinct from metrics of profitability, which address the difference between the revenues obtained from the output and the expense associated with consumption of inputs.

There is considerable evidence that producer-level churning contributes substantially to aggregate (industry) productivity growth, as more productive businesses displace less productive ones. However, productivity has been limited by the fact that producer-level prices are typically unobserved; thus within-industry price differences are embodied in productivity measures. If prices reflect idiosyncratic demand or market power shifts, high "productivity" businesses may not be particularly efficient, and the literature's findings might be better interpreted as evidence of entering businesses displacing less profitable, but not necessarily less productive, exiting businesses. In this paper, we investigate the nature of selection and productivity growth using data from industries where we observe producer-level quantities and prices separately. We show there are important differences between revenue and physical productivity. A key dissimilarity is that physical productivity is inversely correlated with plant-level prices while revenue productivity is positively correlated with the prices. This implies that previous work linking 


\section{International Journal of Science and Research (IJSR) \\ ISSN (Online): 2319-7064}

Index Copernicus Value (2013): 6.14 | Impact Factor (2014): 5.611

(revenue-based) productivity to survive has confounded the separate and opposing effects of technical efficiency and demand on survival, understating the true impacts of both. We further show that young producers charge lower prices than incumbents, and as such the literature understate the productivity advantage of new producers and the contribution of entry to aggregate productivity growth.

\section{DVD}

DVD-R and DVD+R discs can be either single or doublesided. A single-sided (SS) disc is composed of a recording side and a dummy side while a double-sided (DS) disc consists of two recording sides. The recording side of a DVD-R and DVD+R disc is a sandwich of a number of layers. First comes a polycarbonate plastic substrate containing a shallow spiral groove extending from the inside to the outside diameter of the disc. A DVD-R disc additionally includes pits and lands on the areas between the coils of the groove (land pre-pits). Added to this substrate is an organic dye recording layer (azo, cyanine, dipyrromethene or others) followed by a metal reflective layer (silver, silver alloy, gold). The dummy side of a singlesided disc consists of an additional flat polycarbonate plastic substrate (sometimes with an additional metal layer to obscure the bonding layer from view for aesthetic purposes). An adhesive, then bonds two recording sides (for a doublesided) or a recording and a dummy side (for a single-sided) together into the final disc. Some single-sided discs are also tapped on the dummy side with decorations or additional layers that provide surfaces suitable for labeling by inkjet, thermal transfer or re-transfer printers.

\section{DVD Manufacturing Process}

The first step in manufacturing a DVD-R or DVD+R disc is to fabricate the polycarbonate plastic substrates (incorporating the spiral groove and land pre-pits) using an injection molding process. The dye is then applied using spin coating and the metal layers by means of DC sputtering. After both sides of the disc are completed, they are bonded together using a hot melt, UV cationic or free radical process. Additional decoration or printable layers are typically applied using screen printing methods. A DVD-R (General) disc undergoes a further manufacturing step in which a specialized computer DVD recorder is used to "pre writes" information in the Control Data Zone of its Lead-in Area to inhibit direct copying of prerecorded DVD-Video discs encrypted with the Content Scrambling System (CSS).

Apart from this, and some minor differences in the configuration of the molding stumper used to create the substrates, the process for manufacturing DVD-R and $\mathrm{DVD}+\mathrm{R}$ discs are virtually identical. To allow information to not only be written, but also re-written many times over, DVD-RW, DVD+RW and DVD-RAM (rewritable) disc construction is more complex than that of DVD-R and $\mathrm{DVD}+\mathrm{R}$ (recordable). Just like a recordable disc, a rewritable disc can be either single or double-sided. The recording side of a rewritable disc also uses multiple layers beginning with a polycarbonate plastic substrate containing a shallow spiral groove extending from the inside to the outside diameter of the disc. A DVD-RW disc additionally includes pits and lands on the areas between the coils of the groove (land prepits) and a DVD-RAM disc also inside the groove itself (land and groove). Next comes a dielectric layer (zinc sulfide and silicon dioxide), followed by a phase-change alloy recording layer (either indium, silver, tellurium and antimony or germanium, tellurium and antimony), another dielectric layer and a metal reflective layer (silver, silver alloy, aluminum). Additional layers may also be incorporated above or below the dielectric layers (germanium nitride, silicon carbide, silicon dioxide, silicon nitride, zinc sulfide, antimony telluride and others). The dummy side consists of a flat polycarbonate plastic substrate, sometimes with an additional metal layer. An adhesive, then bonds the sides together into a single disc. The exterior of the recording side may also be "hard coated" with a transparent material (indium tin oxide, silicon-based lacquer and others) designed to repel dust and resist fingerprints and scratches. Similar to a barcode in appearance, a DVD-RAM or DVD-RW disc can also contain near its inner diameter an optional Burst Cutting Area (BCA) or Narrow Burst Cutting Area (NBCA) to supply information required to implement Content Protection for Recordable Media (CPRPM). Apart from the thinner substrates and tighter manufacturing tolerances, the most significant difference between writable DVD and CD manufacturing is the need to perfectly bond two DVD halves together to create a disc that is the same thickness as a CD $(1.2 \mathrm{~mm})$. It is imperative that the two disc halves have the same long-term mechanical behavior to ensure that the resulting disc maintains its thermo-mechanical stability. This is particularly important for high-speed discs where flatness and uniformity are paramount. Writable DVD disc manufacturing equipment and production steps (with the addition of the bonding stage) closely resemble those used to fabricate their CD counterparts. In fact, many media manufacturers have simply modified their existing CD-R and CD-RW equipment to produce writable DVD discs, although it is generally expected to become less feasible to do so (for productivity and product quality demands) as the technology and business evolves.

Table 1: Process conditions

\begin{tabular}{|c|c|c|}
\hline Sl. No. & Parameters & Specification \\
\hline 1 & Dye Volume & $0.40+/-0.05 \mathrm{~g}$ \\
\hline 2 & Needle Height & $1.8+0.6 \mathrm{~mm}$ \\
\hline 3 & Airflow on the cup & 0.9 to $1.2 \mathrm{~m} / \mathrm{sec}$ \\
\hline 4 & Dye cup exhaust setting & $1.0-1.6 \mathrm{~m} / \mathrm{sec}$ \\
\hline 5 & Dye pressure & $100 \mathrm{mbar}$ \\
\hline 6 & Humidity & $40 \sim 45 \%+1 \% \mathrm{Rh}$ \\
\hline 7 & Temperature & $25-27.0 * \mathrm{C}+0.25 * \mathrm{C}$ \\
\hline 8 & Needle Angle & $15 \mathrm{degree}$ \\
\hline 9 & Needle diameter & $0.8 \mathrm{~mm}$ \\
\hline 10 & Ionization Pressure & $1.5 \sim 2.0 \mathrm{bar}$ \\
\hline 11 & Dye concentration & $1.40 \mathrm{gm} / 100 \mathrm{cc}$ \\
\hline
\end{tabular}

\subsection{Raw Materials for making DVD}

1) Polycarbonate (PC): It is prime raw material.

2) Dye: Azo Dye (A Powder mixed with TFP or OFP Liquid Solvent).

3) Silver Target: A 4 kg. Silver target which makes 50,000 discs.

4) Methyl Lactate (ML): It is used for removing excess dye and silver particle from disc.

\section{Volume 4 Issue 11, November 2015}




\section{International Journal of Science and Research (IJSR) \\ ISSN (Online): 2319-7064}

Index Copernicus Value (2013): 6.14 | Impact Factor (2014): 5.611

5) Boding Bucket: A kayerd 750 bonding bucket is used for permanent joining of an active disc and a dummy disc.

6) Acetone: It is used for cleaning any part of the PLC machine (Bonding area, Dye area etc.).

7) IPA: It is used for cleaning any part of the PLC machine (Bonding area, Dye area etc.).

\subsection{Operating Station}

Active/dummy molding $\Rightarrow$ Pre-cooler $\Rightarrow$ Input conveyer $\Rightarrow$ Cooler $\Rightarrow$ Dye coating area $\Rightarrow$ Printer $\Rightarrow$ Q.C.1 scanner $\Rightarrow$ Dryer $\Rightarrow$ Metalizer $\Rightarrow$ Edge washing $\Rightarrow$ Bonding $\Rightarrow$ U.V. Cooler $\Rightarrow$ Q.C.2 Scanner $\Rightarrow$ Receiver area.

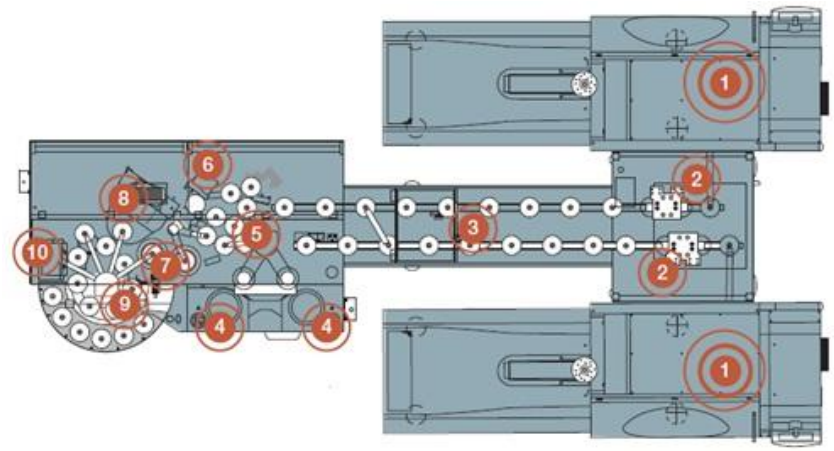

Figure 1: A Typical Layout of DVD Manufacturing Unit

In above fig. 1, (1) Injection moulding (active \& dummy), (2) Pre-cooler, (3) Input conveyor, (4) Metalizer, (5) Edge washing, (6) Delay table, (7) Bonding zone, (8) UV cooler, (9) QC2 scanner, (10) Receiver.

\subsection{Functions of different units in a DVD manufacturing unit}

1) Operation at Active and Dummy Molding: At first Poly Carbonate (PC) is coming into the hopper of the active and dummy molding. The mould has one fixed side and other movable side. The PC comes to a movable part in granular form and melts at $320^{\circ} \mathrm{C}$ then molten $\mathrm{PC}$ come into the fixed side with the help of a nozzle. The active blank disc is made with grooves on the surface by stumper which is fixed at the fixed side of the active molding. In case, dummy blank disc, mirror is used in place of a stumper. So, there will not be any groove in the dummy disc. When fixed and movable mould is closed to each other the blank disc is made in the mould.

2) Operation at the Pre-cooler: From mould the blank disc is collected with the help of the robotic arm. Robotic arm puts the blank disc at pre-cooler pin. Pre-cooler is round shape with at least 8 pins. One robotic arm puts blank disc at pin No. 1 from mould and another robotic arm release blank disc from pin No. 7 to input conveyer. Pin 8 is always empty.

3) Operation at Input Conveyer: In input conveyer there are 23 numbers of pins. In input conveyer there are three numbers of fans for cooling the blank disc to avoid the tilting problem.

4) Operation at Cooler: Cooler has 70 layers (on each layer there are three carriers) in which blank disc come in the down words direction and 71 (on each layer there are three carriers) layers in which blank disc come in to the up words. The main purpose of a cooler is to avoid the tilt of blank disc.

5) Operation in Dye Coating Area: The main function of the dye coating area is to fulfill the dye in active disc.

6) Operation at Printer: In the printer station print the line number, number of days, shift $(\mathrm{A}, \mathrm{B}, \mathrm{C})$ and disc number at the hub of active disc.

7) Operation at Q.C. 1 Scanner: The main function of Q.C.1 scanner is to scan the active disc by a top and a bottom camera. After grading (A, B \& Reject), Q.C.1 scanner rejects the disputed disc, then the active and dummy disc come in the dryer.

8) Operation at Dryer: Dryer has 70 carriers of down words and 71 carriers up words. The main function of the dryer is to control the tilt of the active and dummy disc.

9) Operation at Metalizer: The active disc comes in to the metalizer. In the metalizer $120 \mathrm{~nm}$ silver layer is coated on active disc to increase reflectivity.

10) Operation at Edge Washing: After silver coating of 120 $\mathrm{nm}$ on active disc, it comes into an edge washing area for removing excess dye and silver at the outer area of the active disc using methyl lactated.

11) Operation at Bonding Area: In the bonding area active and dummy disc joint together with the help of glue. After completion of bounding, disc reaches to spin the cup for removing excess glue.

12) Operation at UV Cooler: In UV cooler the complete disc is dried by the heat of ultraviolet ray and active and dummy disc joint properly.

13) Operation at Q.C.2 Scanner: The main function of Q.C.2 scanners is to scan the final disc. After scanning, scanner puts the ok disc in to "A-grade" spindle, middle quality disc in to "B-grade" spindle, disputed disc in to "Reject" spindle.

\section{Attempt to Increase Productivity}

Change in a cycle time of DVD production (from $2.5 \mathrm{Sec}$. per disc to 2 Sec. per disc) was done by changing parameter like molding, pre-cooler, dye conveyer, metalizer conveyer, bonding chuck, curing section etc., At molding, metal melting time was reduced. At pre-cooler, waiting time of the pre-cooler chuck and pre-cooler conveyer was reduced. At dye coating, waiting time at dye conveyer was reduced. At bonding and edge washing area, the RPM of bonding chuck and edge washing chuck were increased. At curing section, power was increased and processing time was reduced.

Reduction in melting time of polycarbonate at moulding by changing heat into the mould was implemented. Starting of the action molding team face lot of problems like silver stick, mount fuzi, and cloud on active, molding team adjusted the molding parameter and heat to combat this problem.

After molding, action was taken at the pre-cooler and cooler. Here waiting time of the pre-cooler and cooler was changed. In starting, scratch on active disc was found due to high speed disc touched on the conveyer. Next action was taken in the dye coating area. At dye coating area, the dye dispenses needle $(0.8 \mathrm{~mm}$ dia to $1.0 \mathrm{~mm}$ dia $)$ was changed and reduction in the processing time. After dye coating, action was taken on the dryer. The dryer is used to heat treatment of 


\section{International Journal of Science and Research (IJSR) \\ ISSN (Online): 2319-7064}

Index Copernicus Value (2013): 6.14 | Impact Factor (2014): 5.611

disc. Here, speed of dryer conveyer was increased manually; here tilt problem was found. After dryer, action was taken on metalizer. Then, the process time of metalizer was reduced. After metalizer, action was taken on bonding area. Here, the R.P.M at bonding chuck and edge working check was increased. After bonding area, speed of receiver handle was increased.

\section{Problems owing to increase in Productivity by Reducing Cycle Time}

At the starting, lot of problems like machine breakdown, low quality of the product was found. At molding, the problem was found on mount Fuji, injection flow, silver stick, cloud, etc. To combat with this problem, molding team adjusted the temperature of melting polycarbonates and adjusts the molding parameter. From dye coating area, problem aroused in face dye cut problem (dye not fill up properly on the disc) and adjusted the parameter of dye coating area to overcome this problem. From bonding area, bonding glue did not reach up to cross mote area. Changed bonding glue and adjusted pressure and temperature of bonding area action were taken to remove this problem. Changed the UV lamp and increased the power of lamp to overcome wet bonding problems.

While numbers of problems were aroused in reducing the cycle time the problems, action taken and action done has given below in the table 2 below:

Table 2: Problems \& action taken

\begin{tabular}{|c|c|c|c|}
\hline \begin{tabular}{|c|} 
Section \\
concerned \\
with the \\
Problem
\end{tabular} & $\begin{array}{l}\text { Nature of } \\
\text { problem }\end{array}$ & $\begin{array}{l}\text { Section } \\
\text { initiated the } \\
\text { action }\end{array}$ & Action taken \\
\hline \multirow[t]{5}{*}{ Molding } & $\begin{array}{l}\text { Injection } \\
\text { flow }\end{array}$ & $\begin{array}{l}\text { Molding } \\
\text { Person }\end{array}$ & - Adjust mold temperature \\
\hline & Mount fuzi & $\begin{array}{l}\text { Molding } \\
\text { Person }\end{array}$ & $\begin{array}{l}\text { - Adjust mold temperature } \\
\text { - Clean the stumper holder }\end{array}$ \\
\hline & Silver Stick & $\begin{array}{l}\text { Molding } \\
\text { Person }\end{array}$ & $\begin{array}{c}- \text { Adjust mold temperature } \\
\text { - Clean the stumper }\end{array}$ \\
\hline & $\begin{array}{l}\text { Dent in inner } \\
\text { hub }\end{array}$ & $\begin{array}{l}\text { Molding } \\
\text { Person }\end{array}$ & $\begin{array}{c}\text { - Change the stumper } \\
\text { holder }\end{array}$ \\
\hline & $\begin{array}{c}\text { Dent on } \\
\text { active side }\end{array}$ & $\begin{array}{l}\text { Molding } \\
\text { Person }\end{array}$ & $\begin{array}{l}\text { - Clean the stumper } \\
\text { - Change the stumper }\end{array}$ \\
\hline \multirow[t]{2}{*}{$\begin{array}{l}\text { Pre-cooler } \\
\text { and input } \\
\text { conveyer }\end{array}$} & Dent in hub & $\begin{array}{c}\text { Production and } \\
\text { maintenance } \\
\text { person }\end{array}$ & - Change the Pre-cooler pin \\
\hline & $\begin{array}{l}\text { Scratch on } \\
\text { active }\end{array}$ & $\begin{array}{c}\text { Production and } \\
\text { maintenance } \\
\text { person }\end{array}$ & $\begin{array}{l}\text { - At first found where this } \\
\text { touch, then adjust the } \\
\text { height of disc and conveyer }\end{array}$ \\
\hline \multirow[t]{2}{*}{$\begin{array}{c}\text { Dye } \\
\text { coating }\end{array}$} & $\begin{array}{c}\text { Dye drop on } \\
\text { disc }\end{array}$ & $\begin{array}{c}\text { Production and } \\
\text { process } \\
\text { engineer }\end{array}$ & $\begin{array}{c}\text { - A retro fill pipe is } \\
\text { adjusted with dye dispense } \\
\text { pipe. } \\
\text { - Clean the dye cup with } \\
\text { schedule }\end{array}$ \\
\hline & $\begin{array}{l}\text { Dye cut } \\
\text { problem }\end{array}$ & $\begin{array}{l}\text { process } \\
\text { engineer }\end{array}$ & $\begin{array}{c}\text { - Adjust the dye dispense } \\
\text { parameter } \\
\text { - Adjust dye density }\end{array}$ \\
\hline
\end{tabular}

\begin{tabular}{|c|c|c|c|}
\hline Dryer & $\begin{array}{l}\text { Scratch on } \\
\text { active }\end{array}$ & $\begin{array}{l}\text { Maintenance } \\
\text { person }\end{array}$ & $\begin{array}{c}\text { - Give Properly allocation } \\
\text { at dryer. } \\
\text { - Change career if it broken }\end{array}$ \\
\hline \multirow[t]{4}{*}{ Metalizer } & Dent in hub & $\begin{array}{l}\text { Production } \\
\text { person \& } \\
\text { Maintenance } \\
\text { person } \\
\end{array}$ & - Change the Metalizer pin \\
\hline & $\begin{array}{l}\text { Crack at } \\
\text { outer }\end{array}$ & $\begin{array}{l}\text { Maintenance } \\
\text { person }\end{array}$ & $\begin{array}{c}\text { - Adjust temperature inside } \\
\text { the metalizer }\end{array}$ \\
\hline & $\begin{array}{l}\text { Mass cut } \\
\text { problem }\end{array}$ & $\begin{array}{l}\text { Production } \\
\text { person }\end{array}$ & - Change the mask \\
\hline & $\begin{array}{c}\text { Yellow band } \\
\text { problem }\end{array}$ & $\begin{array}{l}\text { Production } \\
\text { person }\end{array}$ & - Change the silver target \\
\hline \begin{tabular}{|c|} 
Edge \\
washing
\end{tabular} & Crack at hub & $\begin{array}{c}\text { Production } \\
\text { person \& } \\
\text { Maintenance } \\
\text { person }\end{array}$ & $\begin{array}{l}\text { - Adjust the needle position } \\
\text { - Adjust the methyl lactate } \\
\text { dispense }\end{array}$ \\
\hline \multirow[t]{3}{*}{$\begin{array}{l}\text { Bonding } \\
\text { area }\end{array}$} & $\begin{array}{l}\text { Bonding } \\
\text { Glue not up } \\
\text { to mot area }\end{array}$ & $\begin{array}{l}\text { Production } \\
\text { person \& } \\
\text { process } \\
\text { engineer }\end{array}$ & $\begin{array}{c}- \text { Increase Pressure of } \\
\text { bonding glue } \\
\text { - Increase temperature of } \\
\text { bonding glue } \\
\text { - Take needle position } \\
\text { inside the disk } \\
\end{array}$ \\
\hline & $\begin{array}{l}\text { Bonding } \\
\text { Glue cross } \\
\text { up to mot } \\
\text { area }\end{array}$ & $\begin{array}{l}\text { Production } \\
\text { person \& } \\
\text { process } \\
\text { engineer }\end{array}$ & $\begin{array}{c}\text { - Decrease pressure of } \\
\text { bonding glue } \\
\text { - Decrease temperature of } \\
\text { bonding glue } \\
\text { - Take needle outside the } \\
\text { disc } \\
\end{array}$ \\
\hline & $\begin{array}{l}\text { Resign } \\
\text { bubble at } \\
\text { hub }\end{array}$ & $\begin{array}{l}\text { process } \\
\text { engineer }\end{array}$ & $\begin{array}{l}\text { - Adjust the parameter } \\
\text { - Adjust the pressure and } \\
\text { temperature of bonding } \\
\text { glue }\end{array}$ \\
\hline U.V. unit & $\begin{array}{c}\text { Wet } \\
\text { bonding }\end{array}$ & $\begin{array}{l}\text { Process } \\
\text { engineer }\end{array}$ & $\begin{array}{c}\text { - Increase the power of } \\
\text { U.V. lamp } \\
\text { - Change the U.V. lamp }\end{array}$ \\
\hline
\end{tabular}

\section{Conclusion}

As the cycle time reduction results in higher productivity, less-utilization of manpower, avoids the production delays, reduce inventory, higher customer satisfaction due to the high quality and increases overall efficiency of the plant.

Cycle time reduction has many positive efforts on the manufacturing process of reducing work in process (WIP) to increase output without increasing the resources required to produce the product.

Cycle time reduction plays an important role in improving the competitiveness of DVD manufacturing. Shortening the production cycle time improves the responsiveness to customer demands, and leads to significant profits from yield improvement and cost reduction.

The result showed that reduction of cycle time from $2.5 \mathrm{Sec}$. to $2 \mathrm{Sec}$. increases productivity resulting in cost reduction. 


\section{International Journal of Science and Research (IJSR) \\ ISSN (Online): 2319-7064}

Index Copernicus Value (2013): 6.14 | Impact Factor (2014): 5.611

Table 3: Calculation

\begin{tabular}{|c|c|c|}
\hline & $\begin{array}{c}\text { DVD Production } \\
\text { when cycle time 2.5 } \\
\text { second per disc }\end{array}$ & $\begin{array}{c}\text { DVD Production } \\
\text { when cycle time 2 } \\
\text { sec. per disc }\end{array}$ \\
\hline $\begin{array}{c}\text { DVD Production per } \\
\text { hour (1 Hour }=3600 \\
\text { sec) }\end{array}$ & $=3600 / 2.5=1440$ & $=3600 / 2.0=1800$ \\
\hline $\begin{array}{c}\text { DVD Production per } \\
\text { day (1 Day= 24 }\end{array}$ & $=1440 \times 24=$ & $=1800 \times 24=$ \\
Hours) & 34560 & 43200 \\
\hline $\begin{array}{c}\text { DVD Production per } \\
\text { day (if there is 150 }\end{array}$ & $=34560 \times 150=$ & $=43200 \times 150=$ \\
PLC machine in a & 5184000 & 6480000 \\
company) & & \\
\hline
\end{tabular}

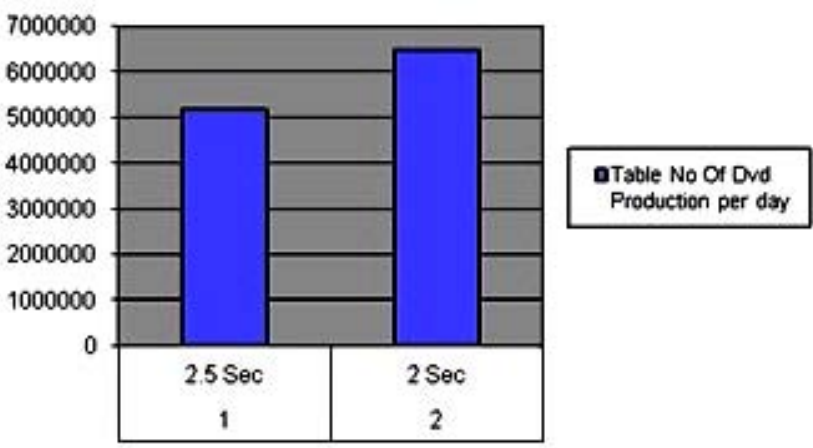

Figure 2: Comparative chart for DVD production w.r.t time

\section{References}

[1] W. J. Stevenson, "Operation Management", Tata McGraw-Hill Education Pvt. Ltd, ISBN-13: 978-0-07066821-8, 2009.

[2] Mark J. Tardibuono, "Improving PWB Productivity By Reducing Process Cycle Time", IPC Conference, San Diego, CA, April 2-6, 2000.

[3] John, Joby, "Fundamentals of Customer-Focused Management: Competing Through Service", Westport, Conn.: Praeger. ISBN 9781567205640, 2003.

[4] Junji Iwasaki, "Productivity Improvement by Cycle Time (CT) Information and its Efficiency Improvement", SEMI/SEMATECH Product and Equipment Time Metrics Workshop, San Francisco Marriott Marquis, July 15, 2010.

[5] "Best of Management Update 1984-1992; Tata Steel Management Development Center”, March 1994.

[6] Sarazen, JS., "The Tools of Quality; Quality Progress", July 1990.

[7] B. Wakhlu, "Total Quality - Excellence through Organization-wide Transformation", A.H. Wheeler \& Co., New Delhi, 1994.

[8] Peter Mears, "Quality Improvement Tools and Techniques", McGraw-Hill Book Company, New York, 1995.

[9] J.R. Evans \& J.W. Dean (Jr.), "Total Quality Management, Organization and Strategy", Thomson Asia Pvt. Ltd., Singapore, 2001.

\section{Author Profile}

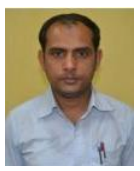

Hasibur Rahaman received the B.E. and M.Tech. degrees in Mechanical Engineering from Jamia Millia Islamia University in 2008 and 2011, respectively. During 2011-2013, he worked as Assistant Professor at Skyline Institute of Engineering and Technology, Gr. Noida, U.P, India. He now with Ghani Khan Choudhury Institute of Engineering and Technology, Malda as Trainer of the Dept. of Mechanical Engineering.

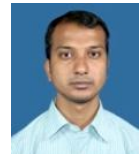

Suman Nihar received the B.E. degree in Mechanical Engineering from Bengal Engineering and Science University, Shibpur (Presently, IIEST-Shibpur) in 2010 and M.E. degree in Mechanical Engineering from Jadavpur University in 2012. He worked as a Sr. Engineer in Technomax Engineering Pvt. Ltd. in designing and production of pipe support. He now with Ghani Khan Choudhury Institute of Engineering and Technology, Malda as Visiting Faculty of the Dept. of Mechanical Engineering.

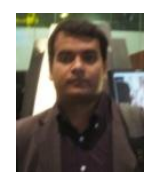

Habib Masum received the B.E. degree in Mechanical Engineering from VTU, Belgaum in 2005 and M.Tech. Degree in Production \& Design Engineering under Mechanical Engineering from NIT, Durgapur in 2007. During 2007-2013, he worked as Sr. Engineer in M.N. Dastur \& Co. (P.) Ltd., Kolkata, India, to design various units of steel plants, power plants and ferro-alloy plants for the nation as well as abroad. He started Ph.D. in IIEST, Shibpur in the year 2010. He now with Ghani Khan Choudhury Institute of Engineering and Technology, Malda as Assistant Professor and Head, Dept. of Mechanical Engineering. 